\title{
Improvement of snowpack simulations in a regional climate model
}

\author{
Jiming $\operatorname{Jin}^{1}$ and Norman L. Miller ${ }^{2 *}$ \\ ${ }^{1}$ Departments of Watershed Sciences and Plants, Soils, and Climate and Utah Climate Center, \\ Utah State University, Logan, UT, USA \\ ${ }^{2}$ Earth Sciences Division, Lawrence Berkeley National Laboratory, Berkeley, CA, USA. \\ *Miller's work is partially supported by the U.S. Department of Energy and LBNL under Contract No. DE- \\ AC02-05CH11231.
}

\begin{abstract}
:
To improve simulations of regional-scale snow processes and related cold-season hydroclimate, the Community Land Model version 3 (CLM3), developed by the National Center for Atmospheric Research (NCAR), was coupled with the Pennsylvania State University/NCAR fifth-generation Mesoscale Model (MM5). CLM3 physically describes the mass and heat transfer within the snowpack using five snow layers that include liquid water and solid ice. The coupled MM5-CLM3 model performance was evaluated for the snowmelt season in the Columbia River Basin in the Pacific Northwestern United States using gridded temperature and precipitation observations, along with station observations. The results from MM5-CLM3 show a significant improvement in the SWE simulation, which has been underestimated in the original version of MM5 coupled with the Noah land-surface model. One important cause for the underestimated SWE in Noah is its unrealistic land-surface structure configuration where vegetation, snow and the topsoil layer are blended when snow is present. This study demonstrates the importance of the sheltering effects of the forest canopy on snow surface energy budgets, which is included in CLM3. Such effects are further seen in the simulations of surface air temperature and precipitation in regional weather and climate models such as MM5. In addition, the snow-season surface albedo overestimated by MM5-Noah is now more accurately predicted by MM5-CLM3 using a more realistic albedo algorithm that intensifies the solar radiation absorption on the land surface, reducing the strong near-surface cold bias in MM5-Noah. The cold bias is further alleviated due to a slower snowmelt rate in MM5-CLM3 during the early snowmelt stage, which is closer to observations than the comparable components of MM5-Noah. In addition, the over-predicted precipitation in the Pacific Northwest as shown in MM5-Noah is significantly decreased in MM5 CLM3 due to the lower evaporation resulting from the longer snow duration.
\end{abstract}

KEY WORDS: land-surface model; regional climate model; snow; vegetation

\section{INTRODUCTION}

In the western United States (WUS), seasonally accumulated snow mass has become increasingly important to water resources, because of the rapidly increasing demand for water to supply the expanding economy and population. Over the last decade, scientists have made a significant effort to understand and forecast snowmass variability in the WUS (Miller et al., 1999; Serreze et al., 1999; Knowles and Cayan, 2002; Jin and Miller, 2007). Observational studies have found a downward trend in snowpack over the last five decades, which is consistent with the smaller ratio of snowfall to rainfall and earlier snowmelt in the WUS, a finding consistent with global warming observations (Mote, 2003; Stewart et al., 2004). Snowmelt timing is also related to winter and spring temperature variability (Dettinger and Cayan, 1995; Cayan et al., 2001). McCabe and Clark (2005) examined eighty-four rivers in the WUS to better understand snowmelt runoff variability and associated climate processes. They found that earlier snowmelt has a high correlation with increased spring and early summer atmospheric pressure and temperature over the WUS, indicating that snowmelt trend and variability is tightly linked to atmospheric forcings. On the other hand, snow mass in the WUS also affects atmospheric processes. Lo and Clark (2002) found that an inverse correlation exists between winter snow cover and subsequent summer monsoon rainfall in the WUS; a similar relationship was previously found in Eurasia by Bamzai and Shukla (1999). This correlation indicates that the land surface often warms up more quickly with a lower snow depth and smaller snow cover area (or conversely, it warms up more slowly with a higher snow depth and larger snow cover area) when compared with normal conditions, suggesting that anomalous snow depth and cover can significantly affect atmospheric circulation patterns. Thus, accurate forecasting of accumulated snow mass and snowmelt timing is essential to both understanding climate variability and managing water resources in the WUS. However, it is very difficult to obtain the detailed observations throughout the WUS, which would allow a full understanding of snow mass and cover variations, as well as related processes. Numerical models are important tools for investigating and quantifying interactions between snow and climate, as well as for the advance of 
Table I. Comparison of CLM3 and the Noah land-surface scheme

\begin{tabular}{cccc}
\hline 2 & \multicolumn{1}{c}{ Vegetation } & Soil & Snow \\
\hline CLM3 & $\begin{array}{c}\text { Up to eight vegetation types in } \\
\text { one grid cell }\end{array}$ & $\begin{array}{c}\text { Ten-layer soil layer including } \\
\text { frozen soil }\end{array}$ & $\begin{array}{c}\text { Five-layer snow including solid } \\
\text { ice, liquid water and } \\
\text { compaction }\end{array}$ \\
Noah & $\begin{array}{l}\text { One vegetation type in one grid } \\
\text { cell }\end{array}$ & $\begin{array}{c}\text { Four-layer soil layer including } \\
\text { frozen soil } \\
\text { the topsoil layer }\end{array}$ & $\begin{array}{c}\text { tayer } \\
\text { thow }\end{array}$ \\
\hline
\end{tabular}

accurate predictions of snow accumulation and melt processes.

In this study, the fifth-generation Mesoscale Model (MM5) developed by the Pennsylvania State University and the National Center for Atmospheric Research (NCAR) is used to simulate the snow water equivalent (SWE) over the Columbia River Basin in the Pacific Northwest, where snow is abundant during the cold season. Chen and Dudhia (2001) coupled the Noah land-surface model that is largely based on Ek and Mahrt (1991) with MM5 to improve the characterizations of land-surface processes with an emphasis on snow-free seasons. However, a study by Jin and Miller (2007) has shown that snowmelt is poorly simulated in MM5-Noah due in large part to an inaccurate spatial allocation of the surface energy in Noah, a result of the deficiencies in the vegetation fraction. Similarly, a 20-year simulation by Leung and Qian (2003) showed that MM5-Noah significantly under-predicts snow depth throughout the WUS. Significant efforts to further advance the Noah model have been made by Ek et al. (2003) and Mitchell et al. (2004), who improved the surface albedo and snow sublimation calculations. In their Noah model version 2.7, the surface albedo is increased and the snow sublimation is suppressed, resulting in an improved snow depth simulation. However, there are still vegetation structure deficiencies in this version of Noah. An off-line Noah test by Livneh et al. (2010) showed that the negative SWE bias could be further alleviated through better descriptions of snow albedo decay and liquid water refreeze. However, our tests with the recent release version of the Weather Research and Forecasting (WRF v3.0) model coupled with the unified Noah (Ek et al., 2003) still showed underestimated SWE (figures not shown). A recent effort has been made by G.-Y. Niu et al. (personal communication) to improve the Noah land-surface scheme with the following additions (the work has been submitted to the Journal of Geophysical Research): (1) a vegetation canopy layer to separate the canopy temperature from the ground temperature; (2) a three-dimensional canopy structure where a modified two-stream radiation transfer scheme is used (Niu and Yang, 2004); and (3) a 3-layer snow model that includes liquid water and variable snow density within the snowpack. From their initial off-line tests, the new version of Noah produced better snow amount and cover simulations. However, this new version of Noah still needs to be coupled with a realistic regional climate model to examine its performance in regional climate systems.
In this study, we have coupled the NCAR-developed Community Land Model version 3 (CLM3) (Oleson et al., 2004), which includes a sophisticated snow scheme, with MM5 to substantially improve the simulations of regional SWE that was underestimated by MM5-Noah, as well as WRF-Noah. Our coupled MM5-CLM3 is evaluated over the Columbia River Basin by comparing it against the results from MM5 with Noah and high-quality observations. This study discusses how the complex physical processes associated with snow, temperature, and precipitation are better tracked with MM5-CLM3, yielding a clearer understanding of the impact of snow on the regional climate of the WUS.

\section{MODEL AND DATA}

As mentioned above, the nonhydrostatic version of MM5 is coupled with CLM3 to improve snow simulation. The results from MM5 to CLM3 are compared with those from MM5 to Noah. Noah v2.7 (Ek et al., 2003) was selected over the two other land-surface schemes (Bucket and Pleim-Xiu) in the newest version of MM5 (Grell et al., 1994), because it is the most sophisticated land-surface model of the three. The Noah model is also used for a broad range of applications and operations at the National Oceanic and Atmospheric Administration (NOAA) (e.g. Pan et al., 2003; Mitchell et al., 2004) and many other institutions.

The comparison of CLM3 and Noah v2.7 is shown in Table I. CLM3 has five snow layers, one vegetation layer and ten soil layers (Oleson et al., 2004). Here, the total soil depth is $3.2 \mathrm{~m}$ with a thin topsoil layer $(1.7 \mathrm{~cm})$ to efficiently capture surface temperature variability. The heat and water flux exchanges between the bottom of the canopy and the snow/soil surface are included in CLM3. Up to eight subgrid cells per model grid cell are introduced into CLM3 to better describe surface heterogeneity. An advanced surface albedo scheme (Dickinson et al., 1993; Bonan, 1996) is adopted to accurately simulate and predict the solar radiation budget at the surface. A two-stream radiation transfer scheme (Dickinson, 1983; Sellers, 1985) is used in CLM3 to characterize shortwave radiation transfer within the canopy.

Noah v2.7 has four soil layers with a total depth of $2 \mathrm{~m}$ and a single slab snow layer lumped with the topsoil layer, which is set to $10 \mathrm{~cm}$. Although vegetation is separated from the soil in Noah v2.7, the heat and water fluxes between the bottom of the canopy and the 
soil/snow surface are not described. In addition, Noah v2.73does not have subgrid cells within its model grid cell, which could result in numerical errors at coarse spatial resolutions.

For convenience, MM5-CLM3 is hereafter referred to as 'MMC' and MM5-Noah as 'MMN'. In both MMC and MMN, all the model atmospheric settings are exactly the same except for their land-surface schemes. In these two versions of MM5, the Grell convection scheme is chosen to parameterize cumulus clouds (Grell, 1993) and the medium range forecast planetary boundary layer (PBL) scheme (Hong and Pan, 1996) is applied to represent boundary layer processes. The microphysics scheme selected is the Simple Ice scheme developed by Dudhia (1989). The NCAR Community Climate Model version 2 radiation scheme (Hack et al., 1993) is selected for describing shortwave and longwave transfer within the atmosphere and to the surface.

In both MMC and MMN, nested simulations using two-way $60 \times 60 \mathrm{~km}$ (domain D1) and $20 \times 20-\mathrm{km}$ (domain D2) resolutions were performed (Figure 1a). The $60 \times 60-\mathrm{km}$ resolution domain (D1) covers the WUS and parts of the eastern Pacific Ocean. The nested $20 \times 20$ $\mathrm{km}$ resolution domain (D2) covers the Pacific Northwest, including the entire Columbia River Basin, where snow is the main water source and is the focus of this analysis. MMC and MMN are both configured with 23 vertical sigma layers from the surface to the $100 \mathrm{hPa}$ level to capture physical processes within the PBL and the upper atmosphere. The National Centers for Environmental Prediction/NCAR (NCEP/NCAR) Reanalysis data at
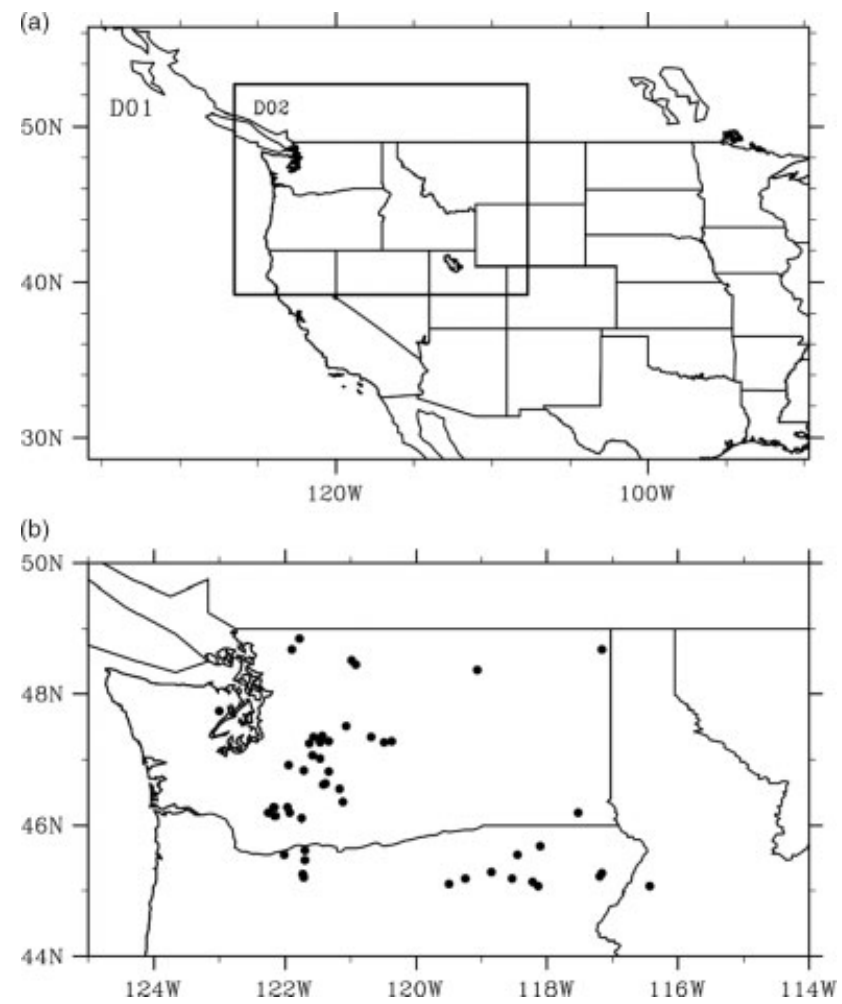

Figure 1. (a) Simulation domains in MMC and MMN; D1 is at $60 \times 60$ $\mathrm{km}$ resolution and $\mathrm{D} 2$ is at $20 \times 20-\mathrm{km}$ resolution. (b) Geographic distribution of the 50 Snotel stations (black dots) $2.5^{\circ} \times 2.5^{\circ}$ resolution (Kalnay et al., 1996) were used as MMC and MMN initial and 6-hourly updated lateral boundary conditions for the period of 1 March to 30 June 2002. Across the WUS, snow usually reaches its maximum amount around 1 April (Serreze et al., 1999) and then starts to melt. Thus, snow accumulation is dominant over snow melt during the first month (March) of our simulation period, but snow melt is the major process during the remaining 3 months (April, May and June).

The observed Snow Telemetry (Snotel) data include daily SWE, temperature at a height of $2 \mathrm{~m}(\mathrm{~T} 2 \mathrm{M})$ and precipitation (used here for model evaluation), which were quality-controlled using the method described in Serreze et al. (1999). Observations from 50 Snotel stations were selected (Figure 1b). All the selected stations are located in Washington and Oregon, except for one in southwestern Idaho. The observed Snotel SWEs were also used for model initialization in both the $60 \times 60 \mathrm{~km}$ and $20 \times 20 \mathrm{~km}$-resolution domains at the corresponding grid cells due to the poor quality of the NCEP/NCAR reanalyzed SWE data.

For model grid cells without Snotel SWE data available, the $0.125^{\circ} \times 0.125^{\circ}$ gridded SWE data produced by the NASA/Land Data Assimilation System (LDAS) were used for the initial conditions. Thus, SWEs in 39 grid cells in the $20 \times 20-\mathrm{km}$ resolution domain were initialized with observations from the 50 Snotel stations located in the Columbia River Basin (Figure 1b), implying that there is more than one Snotel station for some of the model cells. For each of these cells, the initial SWE is the average of the Snotel SWEs. The elevation range for the 50 Snotel stations is between 914 and $2411 \mathrm{~m}$, with a mean elevation of $1360 \mathrm{~m}$. In MMC and MMN, the elevation range at the $20-\mathrm{km}$ resolution is between 637 and $1846 \mathrm{~m}$ over the 39 grid cells in which the Snotel stations are located, with a mean value of $1166 \mathrm{~m}$.

\section{RESULTS}

\section{SWE simulation}

The comparison of observations with simulations of SWE from both MMC and MMN during the March-June melt season is shown in Figure 2. As can be seen from this figure, MMN significantly underestimates the SWE (dotted line), whereas MMC (dashed line) agrees well with observations (solid line). The average bias over the simulation period for $\mathrm{MMN}$ is $-286 \mathrm{~mm}$, but is only $9 \mathrm{~mm}$ for MMC.

To fully understand the performance of snow simulation by the two models, the following energy-balance equation is examined:

$$
(1-\alpha) \mathrm{SW} \downarrow+\mathrm{LWNET}-\mathrm{LHF}-\mathrm{SHF}-\mathrm{GF}=0
$$

where $\alpha$ is the surface albedo, SW $\downarrow$ the downward solar radiation, LWNET the net longwave radiation, LHF the latent heat flux, SHF the sensible heat flux and GF the ground heat flux. The calculated snowmelt rates 

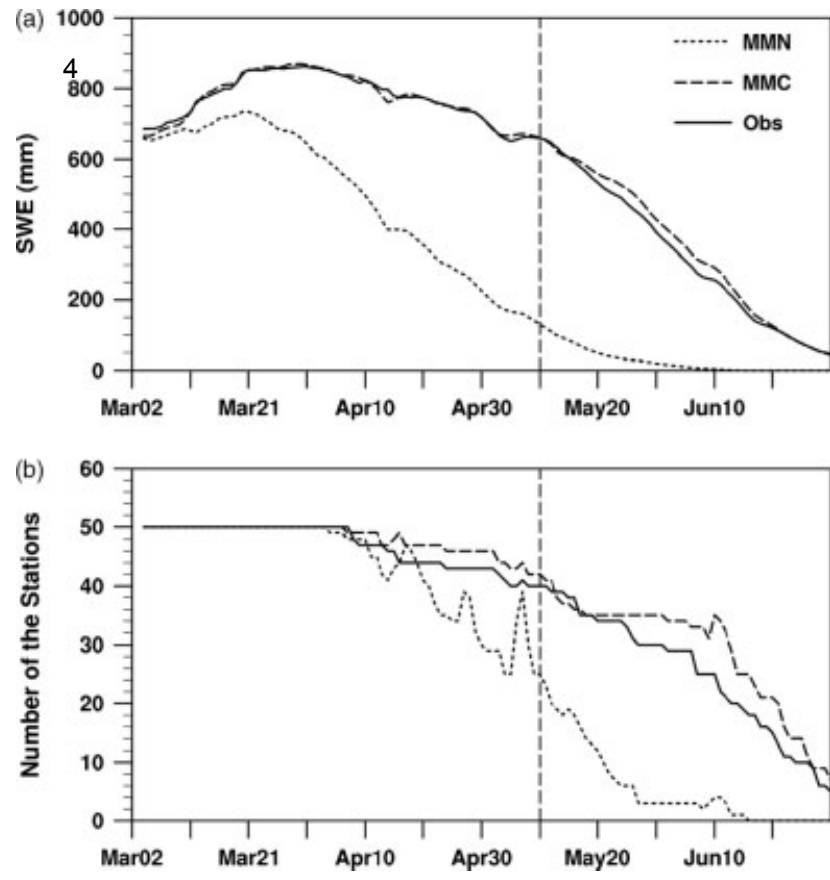

Figure 2. (a) Comparison of observed (solid line) and simulated SWEs (mm) from MMC (dashed line) and MMN (dotted line) averaged over the 50 Snotel stations for 2 March to 30 June 2002. (b) The same as (a), but for the numbers of Snotel stations at which snow is present. The dashed vertical line at 11 May 2002 is the division between periods PA and $\mathrm{PB}$, which is explained in the Section on SWE Simulation

(SMRs) are based on the time series of SWE and indicate that from 2 March to 11 May 2002 (see the vertical dashed line in Figure 2a) the snowmelt is faster in MMN $(9 \mathrm{~mm} /$ day) than in MMC (4 mm/day, the same as the observed value). However, from 12 May to 30 June the average SMR is $2 \mathrm{~mm} /$ day in MMN, whereas it is $12 \mathrm{~mm} /$ day in MMC, which matches the observations for this period.

Thus, the simulation period can be seen as having two separate segments. The first segment is from 2 March to 11 May, defined as 'PA (period A)', and the second segment is from 12 May to 30 June, defined as 'PB (period B)'. The thick, dashed, vertical line in Figures 2a and $\mathrm{b}$ is the division between these two periods. Table II shows the comparison of variables in the energy balance equation (Equation (1)) between MMC and MMN. This indicates that the higher albedo in MMN (0.46 vs 0.29 in MMC) during PA partially contributes to lower net solar radiation $\left(115 \mathrm{Wm}^{-2}\right)$ at the surface. In spite of the lower net surface solar radiation, the ground heat flux (downward is positive) during PA in MMN is $22 \mathrm{Wm}^{-2}$ larger than in MMC, implying that the ground surface receives more energy to melt snow in MMN when snow exists. The average ground heat flux is $43 \mathrm{Wm}^{-2}$ in $\mathrm{MMN}$ and $21 \mathrm{Wm}^{-2}$ in MMC, possibly explaining the larger MMN SMR. The net surface solar radiation in MMC consists of two parts, one absorbed by the vegetation and the other by the ground surface. The total net surface solar radiation is $138 \mathrm{Wm}^{-2}$ during PA, where $119 \mathrm{Wm}^{-2}$ is absorbed by the vegetation and $19 \mathrm{Wm}^{-2}$ by the ground surface. However, without formulating a vegetation fraction in $\mathrm{MMN}$, we find that the ground surface received $115 \mathrm{Wm}^{-2}$ of solar radiation, a key reason for the faster snowmelt.

During PB, the average ground heat flux is $19 \mathrm{Wm}^{-2}$ in $\mathrm{MMN}$ and $58 \mathrm{Wm}^{-2}$ in $\mathrm{MMC}$, which shows that a stronger heat flux enters the snow surface in MMC, consistent with its faster SMR (12 mm/day in MMC vs $2 \mathrm{~mm} /$ day in MMN). In fact, the slower SMR in MMN results from the mathematical averaging processes rather than physical processes. To understand the SMR differences between the two models, we study the snow presence at the 50 Snotel stations spread across 39 model grid cells (Figure $2 b$ ). Figure $2 b$ shows the time evolution for the numbers of these stations at which snow is present. The average SMR is calculated here as the sum of the SMRs over the 50 Snotel stations divided by 50 . If there is no snow at a station, the SMR will be equal to zero at this station. In this case, the average SMR over all the stations will be mathematically reduced even if SMRs at the other stations remain unchanged. In Figure $2 b$, the number of Snotel stations with snow present in MMN is smaller than in MMC during the later PA period, but the average SMR in MMN (9 mm/day) is faster than in MMC (4 mm/day), with a $5 \mathrm{~mm} /$ day difference. Therefore, physically speaking, if only the Snotel stations with snow were examined in both models, the difference would be larger.

At the beginning of PB (12 May), there are 41 Snotel stations with snow present in MMC (more than one Snotel station present some grid cells), 39 for the observations, but only 20 in MMN. After 14 June, no snow exists at any Snotel station in MMN, but there are still 25 in MMC and 18 for the observations.

Table II. Temperatures $\left({ }^{\circ} \mathrm{C}\right)$, snowmelt rate $(\mathrm{SMR})\left(\mathrm{mm} /\right.$ day) and the components $\left(\mathrm{Wm}^{-2}\right)$ in the energy-balance equation [Equation (1)] averaged over the 50 Snotel stations for 2 March to 11 May 2002 and 12 May to 30 June 2002

\begin{tabular}{|c|c|c|c|c|c|c|c|c|c|c|}
\hline & $\mathrm{T} 2 \mathrm{M}$ Bias & $\mathrm{T} 2 \mathrm{M}$ & TG & SMR & Alb & (1-Alb)SW $\downarrow$ & LWNET & LHF & SHF & GF \\
\hline \multicolumn{11}{|c|}{2 March to 11 May 2002} \\
\hline MMC & -0.5 & $-0 \cdot 5$ & -0.8 & 4.0 & $0 \cdot 29$ & 138 & -61 & 21 & 35 & 21 \\
\hline MMN & -2.7 & -2.7 & $-3 \cdot 8$ & $9 \cdot 0$ & 0.46 & 115 & -52 & 22 & -2 & 43 \\
\hline $\mathrm{MMC}-\mathrm{MMN}$ & & $2 \cdot 2$ & $3 \cdot 0$ & $-5 \cdot 0$ & $-0 \cdot 17$ & 23 & -9 & -1 & 37 & -22 \\
\hline \multicolumn{11}{|c|}{12 May to 30 June 2002} \\
\hline $\mathrm{MMC}$ & -0.5 & $8 \cdot 1$ & $7 \cdot 8$ & $12 \cdot 0$ & $0 \cdot 19$ & 222 & -74 & 30 & 60 & 58 \\
\hline MMN & $-0 \cdot 2$ & $8 \cdot 4$ & $8 \cdot 8$ & $2 \cdot 0$ & $0 \cdot 16$ & 201 & -64 & 67 & 51 & 19 \\
\hline MMC-MMN & & $-0 \cdot 3$ & $-1 \cdot 0$ & $10 \cdot 0$ & 0.03 & 21 & -10 & -37 & 9 & 39 \\
\hline
\end{tabular}


Thus, during PB the average SMR for observation and MME simulation is $12 \mathrm{~mm} /$ day, but in MMN it is only $2 \mathrm{~mm} /$ day, which is largely attributable to the numerical calculation. However, if a single grid cell is examined across a period in which snow is present, faster snowmelt is always seen in MMN compared with the corresponding observation and MMC SMR (figure not shown).

Faster snowmelt in MMN results mainly from deficiencies in the vegetation structure, resulting in solar radiation not being intercepted by the vegetation in this dense forest area, where the vegetation fraction in April reaches 64\% [averaged over the Snotel stations based on the available Sea-viewing Wide Field-of-view Sensor (SeaWiFS) satellite vegetation fraction data]. In an earlier study it was shown that the MMN model configuration allows all the solar radiation to reach the snow surface in such vegetated areas (Jin and Miller, 2007). Even though a higher surface albedo during PA in MMN tends to reflect more surface solar radiation, it is still unable to eliminate the large snowmelt bias. In MMC, the lower albedo during the same period enables the land surface to receive a larger percentage of solar radiation than in MMN and less radiation reaches the snow surface (due to vegetation interception). This results in a slower SMR in MMC than in MMN, but is closer to the observation.

\section{Air temperature simulation}

Figure 3 shows the time series of the T2M ( $2 \mathrm{~m}$ height air temperature) simulations and observations averaged over the 50 Snotel stations. Both MMC and MMN closely simulate the variability of the observed temperature: The correlation between the MMN simulation and the observation is 0.91 and between the MMC simulation and the observation is 0.93 . However, the bias produced by $\mathrm{MMN}$ is $-1.7^{\circ} \mathrm{C}$ compared to $-0.5^{\circ} \mathrm{C}$ in MMC. Figure 3 shows that the most significant difference between the two models occurs during PA, where the bias in $\mathrm{MMN}$ is $-2.7^{\circ} \mathrm{C}$, but in $\mathrm{MMC}$ it is $-0.5^{\circ} \mathrm{C}$. During $\mathrm{PB}$, the bias in MMC is still $0.5^{\circ} \mathrm{C}$, whereas in MMN it is only $0.2^{\circ} \mathrm{C}$, although the overall MMC shows a significantly greater improvement in temperature simulation. Analysis of the energy-balance components (Table IIa) indicates that during PA, MMC has greater solar radiation absorption at the surface than MMN, due to the lower surface albedo.

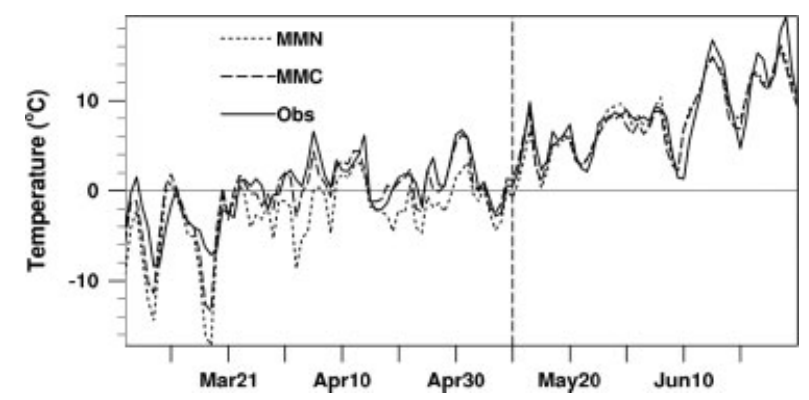

Figure 3. Comparison of observed (solid line) and simulated air temperature $\left({ }^{\circ} \mathrm{C}\right)$ at $2 \mathrm{~m}$ from MMC (dashed line) and MMN (dotted line) averaged over the 50 Snotel stations for 2 March to 30 June 2002. The dashed vertical line at 11 May 2002 is the division between the PA and PB periods
Meanwhile, the ground heat flux is weaker in MMC than in MMN, partially due to less energy consumption by snowmelt in MMC. These two processes increase the surface skin temperature (TG) by $3{ }^{\circ} \mathrm{C}$ in MMC. In addition to the larger sensible heat flux (a $37 \mathrm{~W} / \mathrm{m}^{2}$ increase), the MMC T2M increases by $2 \cdot 2^{\circ} \mathrm{C}$, which is much closer to the observed value than that of MMN.

During $\mathrm{PB}$, the $\mathrm{TG}$ in $\mathrm{MMC}$ is $1{ }^{\circ} \mathrm{C}$ lower than in MMN, where both are averaged over the Snotel stations. An analysis of all the energy balance components shows that the TG reduction is caused by the larger ground heat flux $\left(58 \mathrm{Wm}^{-2}\right)$ entering the surface, resulting from the higher snowmelt during this period predicted by MMC (12 $\mathrm{mm} /$ day) than predicted by MMN ( $2 \mathrm{~mm} /$ day $)$. In addition, when compared with MMN, MMC forecasts a slight decrease in net longwave radiation $\left(-10 \mathrm{Wm}^{-2}\right)$ and a larger sensible heat flux $\left(9 \mathrm{Wm}^{-2}\right)$, which also contributes to the TG reduction. In most land-surface models such as CLM3 or Noah, T2M is treated as a function of TG and sensible heat flux. Although sensible heat flux is stronger in MMC than in MMN, it is apparent that the lower TG in MMC has a more dominant effect on $\mathrm{T} 2 \mathrm{M}$, resulting in a $0.3{ }^{\circ} \mathrm{C}$ decrease. Moreover, the surface albedo in MMC is 0.03 higher than in MMN (Table IIb) due to the longer snow duration in MMC (Figure 2). However, MMC still generates larger net solar radiation $\left(21 \mathrm{Wm}^{-2}\right)$ at the surface as a result of greater downward solar radiation $\left(269 \mathrm{Wm}^{-2}\right.$ in MMC $v s$ $240 \mathrm{Wm}^{-2}$ in MMN during PB). The stronger downward solar radiation results from the smaller cloud fraction, which in MMC decreases by $10 \%$ in low altitude clouds (below $800 \mathrm{hPa}$ ), 5\% in middle altitude clouds (between $800 \mathrm{hPa}$ and $450 \mathrm{hPa}$ ) and remains unchanged in high altitude clouds (above $450 \mathrm{hPa}$ ). MMC shows a strong decrease in latent heat flux $\left(-37 \mathrm{Wm}^{-2}\right)$, resulting in less water supplied to the atmosphere and apparently contributing to the smaller cloud fraction. The $1{ }^{\circ} \mathrm{C}$ TG reduction in MMC partially leads to this weaker latent heat flux. Another factor found to lower evaporation is soil moisture content. The slower SMR in MMC during PA provides less liquid water to the soil, resulting in a $5.1 \%$ reduction in the $1 \mathrm{~m}$ mean volumetric soil moisture content. Although a faster SMR occurs during PB in MMC, the soil moisture content is still $2.5 \%$ lower than in MMN, which contributes to lower evaporation.

Therefore, when compared with MMN, MMC more realistically reproduces the averaged near-surface air temperature based on measurements from the Snotel stations, especially during PA. This improvement results from lower surface albedo and weaker ground heat flux that slows the snowmelt in MMC (observation: $4 \mathrm{~mm} /$ day; MMC: $4 \mathrm{~mm} /$ day; MMN: $9 \mathrm{~mm} /$ day). Although the MMC temperature bias during $\mathrm{PB}$ does not change significantly, the values of some MMC energy balance variables are very different from those in MMN, such as ground heat flux, latent heat flux and net solar radiation. Without sufficient observations, the realistic values of energy components cannot be adequately determined. However, given the higher accuracy of the snowmelt 

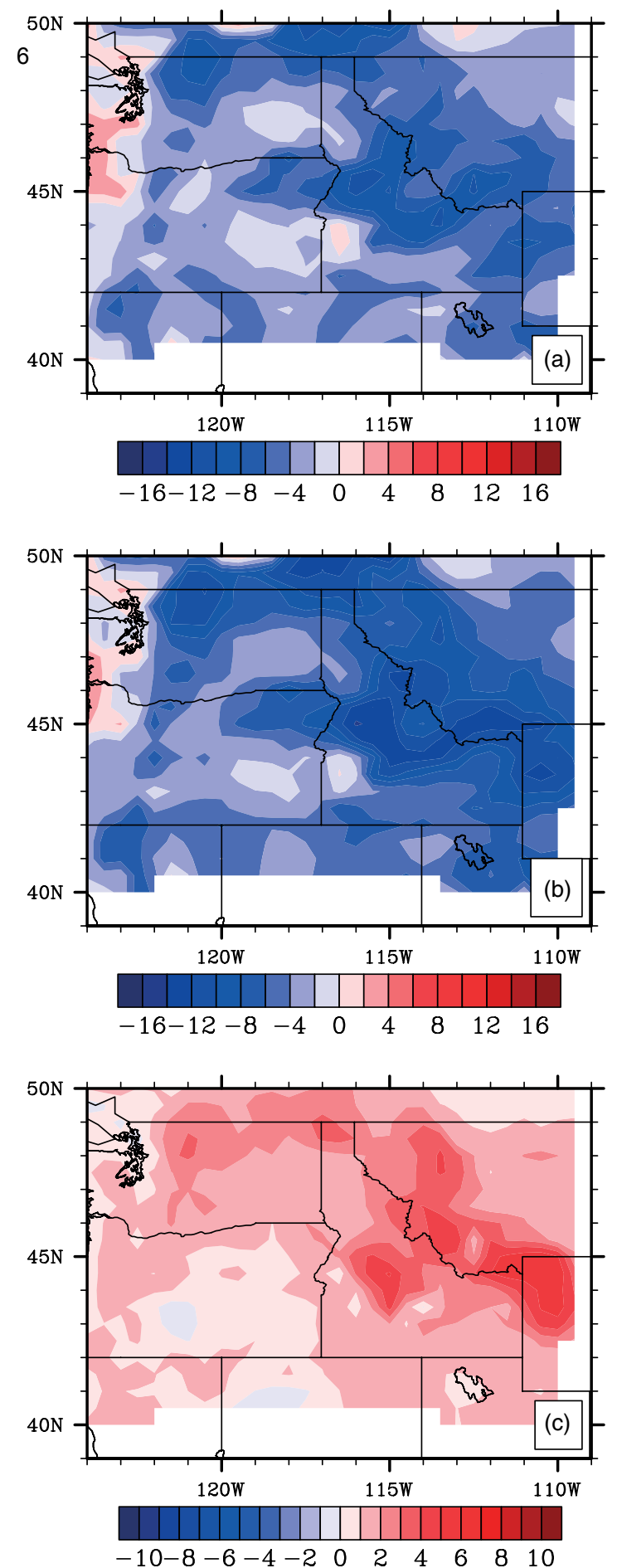

Figure 4. (a) Geographic distributions of the simulated 2-m air temperature biases from (a) MMC and (b) MMN (the contour interval is $2^{\circ} \mathrm{C}$ ) as well as (c) the simulated 2-m air temperature differences between these two models (MMC-MMN) (the contour interval is $1^{\circ} \mathrm{C}$ )

simulated in MMC during PB (observation: $12 \mathrm{~mm} /$ day; MMC: $12 \mathrm{~mm} /$ day; MMN: $2 \mathrm{~mm} /$ day), the ground heat flux simulation in MMC can be assumed to be more accurate because it is closely related to the SMR during the snow season.

Figure 4 shows the spatial distribution of T2M biases in MMN and MMC at $20 \times 20-\mathrm{km}$ resolution averaged over 2 March to 30 June 2002. To calculate the biases,

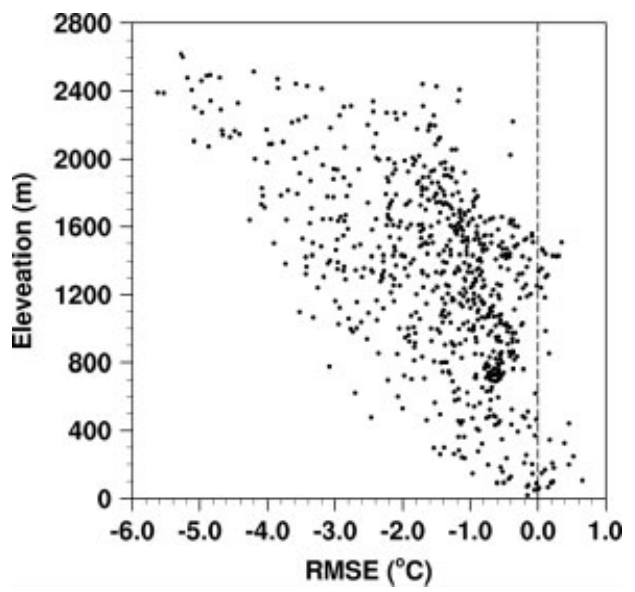

Figure 5. RMSE differences of 2-m air temperature $\left({ }^{\circ} \mathrm{C}\right)$ between MMC and MMN versus elevation $(\mathrm{m})$ over the $20 \times 20-\mathrm{km}$ resolution domain (MMC-MMN). Each black dot represents one model grid cell

the simulated $20 \times 20$-kmresolution data from MMC and $\mathrm{MMN}$ are interpolated to the observation resolution $\left(0.5^{\circ} \times 0.5^{\circ}\right)$. Figure 4 shows that the T2M cold biases cover nearly the entire $20 \times 20-\mathrm{km}$ resolution domain in both models, but MMC has a significantly smaller bias. The largest T2M improvement, with more than a $4-5{ }^{\circ} \mathrm{C}$ increase in MMC, occurs in the northwest region of Wyoming, western Montana and central Idaho. These improvements are seen more clearly in Figure 4c, which gives the T2M difference between MMC and MMN. Figure 5 shows the change of the temperature root mean square error (RMSE) difference with elevation (MMC minus MMN). This figure indicates that except for a few points, errors decrease over the entire domain and the error reduction shows a trend from lower to higher elevation, indicating that snow plays an important role in improving the MMC temperature simulation.

Surface albedo also plays a significant role in temperature differences between MMC and MMN. Figure 6 shows monthly albedos from MMC, MMN and the SeaWiFS satellite data averaged over the 50 Snotel stations (Figure 6a) and the $20 \times 20-\mathrm{km}$ resolution domain (Figure 6b) during our simulation period (satellite data are available only in March and April). When compared with observations (dark bars), MMC is able to reasonably reproduce the observed surface albedo (grey bars), whereas MMN over-predicts albedo by more than $43 \%$ in March and April (white bars).

\section{Precipitation simulation}

In this section, a physical analysis of precipitation changes between MMC and MMN is presented. Figure 7 shows the time series of the observed and simulated daily precipitation averaged over the 50 Snotel stations. Generally, both MMC and MMN reproduce observations at the Snotel stations. However, the precipitation bias in MMN is 38 and $26 \mathrm{~mm} / \mathrm{month}$ in MMC (a $12 \mathrm{~mm} / \mathrm{month}$ decrease) over our study period.

Figure 8 shows the spatial distribution bias for simulated monthly precipitation from 2 March to 30 June 

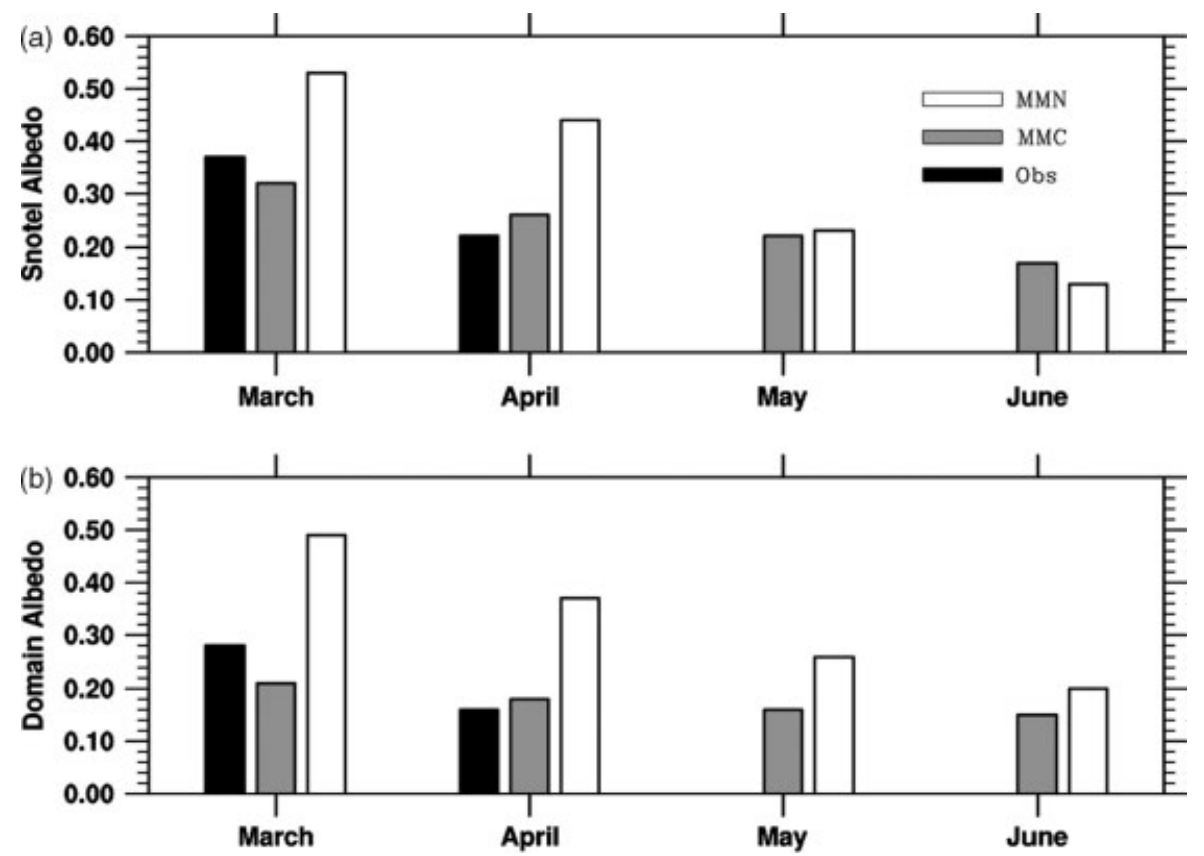

Figure 6. Monthly albedo from MMC (grey bars), MMN (white bars) and the SeaWiFS satellite data (dark bars) for the period of March, April, May and June 2002 averaged (a) over the 50 Snotel stations and (b) over the entire $20 \times 20$-km resolution domain. The SeaWiFS satellite albedos for May and June are not available

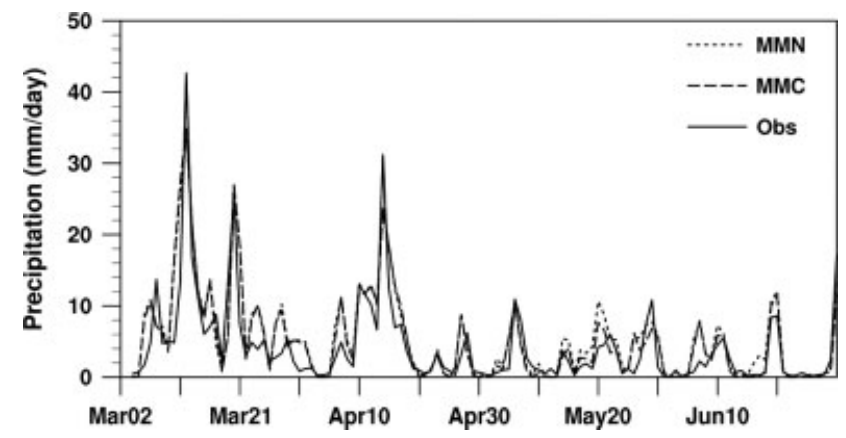

Figure 7. Comparison of observed (solid line) and simulated precipitation (mm/day) from MMC (dashed line) and MMN (dotted line) averaged over the 50 Snotel stations for 2 March to 30 June 2002

2002. In MMN, the domain-wide average precipitation bias over the simulation period is $20 \mathrm{~mm} / \mathrm{month}$, while in MMC it is $16 \mathrm{~mm} /$ month. Both models over-estimate precipitation, except in some small areas such as northwestern Wyoming and western Montana, where negative biases are found. However, MMC reduces the positive biases in regions of Oregon, Washington, Idaho and Montana (Figure 8c). The most significant bias reductions in MMC are seen in northeastern Oregon, central Idaho and northwestern Montana, where a bias reduction of more than $10 \mathrm{~mm} /$ month occurs. Evaporation differences between MMC and MMN are examined. The $20 \times 20$ $\mathrm{km}$ domain average evaporation in MMC is $7 \mathrm{~mm} / \mathrm{month}$ lower than in MMN and the corresponding precipitation in MMC decreases by $4 \mathrm{~mm} / \mathrm{month}$, which is closer to observations than the precipitation decrease in MMN. Lower evaporation results from longer snow duration in MMC as discussed above. Therefore, a better snowpack simulation improves both temperature and precipitation simulations.

\section{CONCLUSIONS AND DISCUSSION}

The objective of this study is to improve regional snow simulations and better understand how snow physically affects temperature and precipitation simulations in a regional climate model. To achieve this objective, we coupled MM5 with the NCAR-CLM3 code that includes a sophisticated snow scheme. This model coupling and analysis aim to contribute toward a better understanding of physical processes and phenomena in the regional climate system.

Results from the coupled MM5-CLM3 are compared with MM5-Noah. We found that MM5-CLM3 dramatically improves the SWE simulation over the Snotel stations, which is underestimated by MM5-Noah. Meanwhile, MM5-CLM3 significantly alleviates the overestimated precipitation and cold bias at the $20 \times 20-\mathrm{km}$ resolution domain demonstrated by MM5-Noah. The improvement in surface air temperature simulation results from lower albedo and slower snowmelt in MM5-CLM3. The overestimated precipitation in MM5-Noah is lowered to some extent in MM5-CLM3 due to weaker surface evaporation resulting from longer snow duration.

Although MM5-CLM3 improves SWE, surface temperature and precipitation predictions as compared with MM5-Noah, it does not completely eliminate biases in these variables, suggesting that land-surface schemes will continue to require further refinement and evaluation. In addition, to achieve more accurate simulation and forecasting for regional weather, climate and water resources, other physical and dynamic processes in regional climate models - such as radiation, topography and cumulus parameterizations - need to be more adequately calibrated and evaluated. Future work will be 

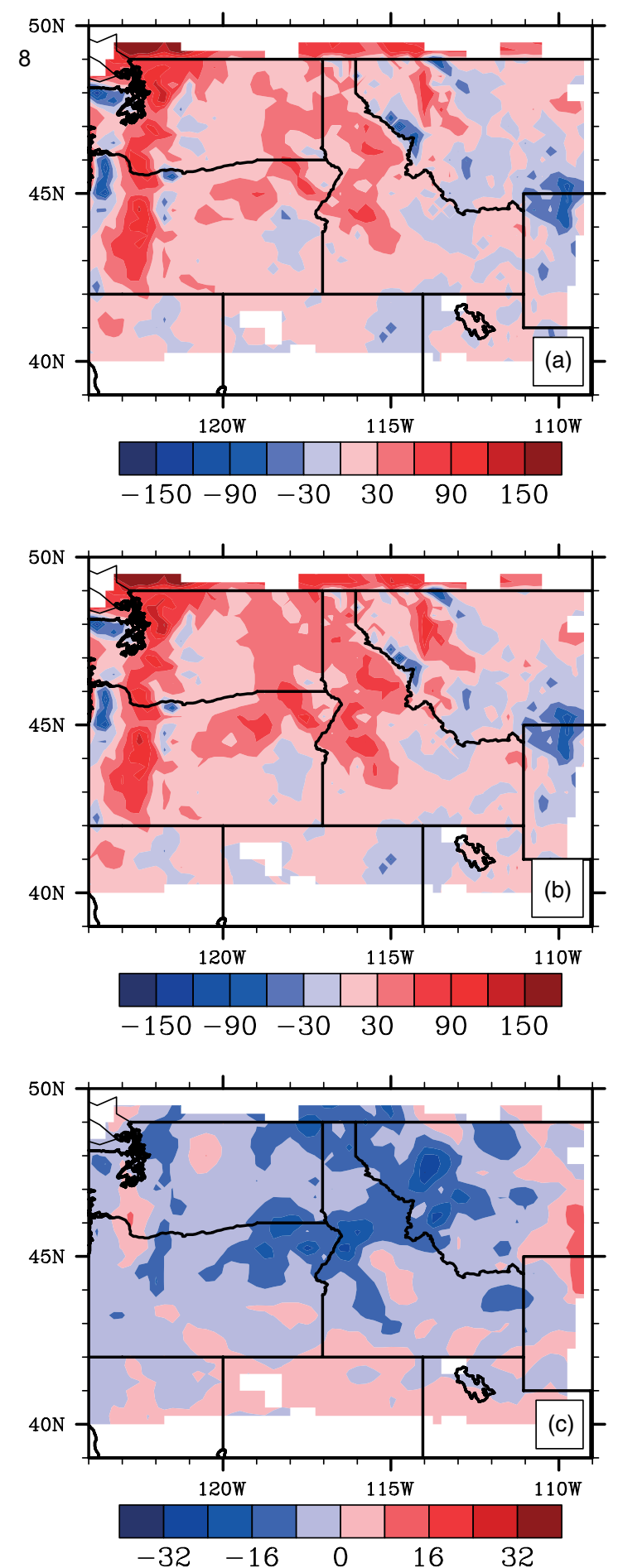

Figure 8. Geographic distribution of the simulated precipitation biases from (a) MMC and (b) MMN as well as (c) the simulated precipitation differences between these two models (MMC-MMN) (Unit: $\mathrm{mm} / \mathrm{month}$ )

focused on applications of this coupled model to broader areas under different weather and climate conditions.

\section{ACKNOWLEDGEMENTS}

The authors want to thank Drs Kenneth Mitchell, Helin Wei from NOAA and the three anonymous reviewers for useful comments, which have improved the quality of this study. Jiming Jin was supported by the Utah Agricultural
Experiment Station, USDA Special Grants No. 200934610-19925, EPA RD83418601 and the NOAA MAPP NA090AR4310195 grant.

\section{REFERENCES}

Bamzai AS, Shukla J. 1999. Relation between Eurasian snow cover, snow depth, and the Indian summer monsoon: an observational study. Journal of Climate 12: 3117-3132. DOI: 10.1175/1520-0442.

Bonan GB. 1996. A Land Surface Model (LSM Version 1.0) for Ecological Hydrological and Atmospheric Studies: Technical Description and User's Guide. NCAR Technical Note NCAR/TN-417+STR. National Center for Atmospheric Research: Boulder, CO.

Cayan DR, Kammerdiener SA, Dettinger MD, Caprio JM, Peterson DH 2001. Changes in the onset of spring in the Western United States. Bulletin of the American Meteorological Society 82: 399-415.

Chen F, Dudhia J. 2001. Coupling an advanced land-surface/hydrology model with the Penn State/NCAR MM5 modeling system. Part I: model implementation and sensitivity. Monthly Weather Review 129: 569-585.

Dettinger MD, Cayan DR. 1995. Large-scale atmospheric forcing of recent trends towards early snowmelt runoff in California. Journal of Climate 8: 606-623.

Dickinson RE. 1983. Land surface processes and climate-surface albedos and energy balance. Advances in Geophysics. Academic Press: New York, USA; 48.

Dickinson RE, Henderson-Sellers A, Kennedy PJ. 1993. Biosphere Atmosphere Transfer Scheme (BATS) Version le as Coupled to the NCAR Community Climate Model. NCAR Technical Note, NCAR/TN387+STR; 72 .

Dudhia J. 1989. Numerical study of convection observed during winter monsoon experiment using a mesoscale two-dimensional model. Journal of the Atmospheric Sciences 46: 3077-3101.

Ek M, Mahrt L. 1991. OSU 1-D PBL Model User's Guide. Version 1.04, Department of Atmospheric Sciences, Oregon State University, Corvallis, OR; 120.

Ek MB, Mitchell KE, Lin Y, Rogers E, Grunmann P, Koren V, Gayno G, Tarpley JD. 2003. Implementation of Noah land surface model advances in the National Centers for Environmental Prediction operational mesoscale Eta model. Journal of Geophysical Research 108(D22): 8851. DOI: 10.1029/2002JD003296.

Grell G. 1993. Prognostic evaluation of assumptions used by cumulus parameterizations. Monthly Weather Review 121: 764-787.

Grell G, Dudhia J, Stauffer D. 1994. A Description of the Fifthgeneration Penn State/NCAR Mesoscale Model (MM5). NCAR Tech. Note NCAR/TN-398 + STR; 117.

Hack JJ, Boville BA, Briegleb BP, Kiehl JT, Rasch PJ, Williamson DL. 1993. Description of the NCAR Community Climate Model (CCM2). NCAR Tech. Note NCAR/TN-3821STR.

Hong S-Y, Pan H-L. 1996. Nonlocal boundary layer vertical diffusion in a medium-range forecast model. Monthly Weather Review 124: $2322-2339$

Jin J, Miller NL. 2007. Impact of snow on the weather variability in the Sierra Nevada region. Journal of Hydrometeorology 8: 245-258.

Kalnay E, Kanamitsu M, Kistler R, Collins W, Deaven D, Gandin L, Iredell M, Saha S, White G, Woolen J, Zhu Y, Chelliah M, Ebisuzaki W, Higgins W, Janowiak J, Mo KC, Ropelewski C, Wang J, Leetma A, Reynolds R, Jenne R, Joseph D. 1996. The NCEP/NCAR 40-year reanalysis project. Bulletin of the American Meteorological Society 77: 437-471.

Knowles N, Cayan DR. 2002. Potential effects of global warming on the Sacramento/San Joaquin watershed and the San Francisco estuary. Geophysical Research Letters 29(18): 1891.

Leung LR, Qian Y. 2003. The sensitivity of precipitation and snowpack simulations to model resolution via nesting in regions of complex terrain. Journal of Hydrometeorology 4(6): 1025-1043.

Livneh B, Xia Y, Mitchell KE, Ek MB, Lettenmaier DP. 2010. Noah LSM snow model diagnostics and enhancements. Journal of Hydrometeorology 11: 721-738.

Lo F, Clark PM. 2002. Relationships between spring snow mass and summer precipitation in the southwestern United States associated with the North American monsoon system. Journal of Climate 15: $1378-1385$.

McCabe GJ, Clark PM. 2005. Trend and variability in snowmelt runoff in the western United States. Journal of Hydrometeorology 6(4): 476-482. 
Miller NL, Kim J, Hartman RK, Farrara J. 1999. Downscaled climate and streamflow study of the southwestern United States. Journal of the American Water Resources Association 35: 1525-1537.

Mitchell KE, Lohmann D, Houser PR, Wood EF, Schaake JC, Robock A, Cosgrove BA, Sheffield J, Duan Q, Luo L, Higgins RW, Pinker RT, Tarpley JD, Lettenmaier DP, Marshall CH, Entin JK, Pan M, Shi W, Koren V, Meng J, Ramsay BH, Bailey AA. 2004. The multi-institution North American Land Data Assimilation System (NLDAS): utilizing multiple GCIP products and partners in a continental distributed hydrological modeling system. Journal of Geophysical Research 109: D07S90. DOI: 10.1029/2003JD003823.

Mote PW. 2003. Trends in snow water equivalent in the Pacific Northwest and their climatic causes. Geophysical Research Letters 30: DOI 10.1029/2003GL0172588.

Niu G-Y, Yang Z-L. 2004. Effects of vegetation canopy processes on snow surface energy and mass balances. Journal of Geophysical Research 109: D23111. DOI: 10.1029/2004JD004884.

Oleson KW, Dai Y, Bonan G, Bosilovich M, Dickinson R, Dirmeyer P, Hoffman F, Houser P, Levis S, Niu G-Y, Thornton P, Vertenstein M,
Yang Z-L, Zeng X. 2004. Technical Description of the Community Land Model (CLM), NCAR/TN-461+STR; 174.

Pan M, Wood EF, Sheffield J, Wen F, Mitchell KE, Houser PR, Schaake JC, Robock A, Lettenmaier DP, Lohmann D, Cosgrove BA, Duan Q, Luo L, Higgins RW, Pinker RT, Tarpley JD, Ramsay BH. 2003. Snow process modeling in the North American Land Data Assimilation System (NLDAS): 2. Evaluation of model simulated snow water equivalent. Journal of Geophysical Research 108(D22): 8850. DOI: 10.1029/2003JD003994.

Sellers PJ. 1985. Canopy reflectance, photosynthesis and transpiration. International Journal of Remote Sensing 6: 1335-1372.

Serreze MC, Clark MP, Amstrong RL, McGinnis DA, Pulwarty RS. 1999. Characteristics of western U.S. snowpack from SNOTEL data. Water Resources Research 35: 2145-2160.

Stewart I, Cayan DR, Dettinger MD. 2004. Changes in snowmelt runoff timing in western North America under a "Business as Usual" climate change scenario. Climatic Change 62: 217-232. 


\section{DISCLAIMER}

This document was prepared as an account of work sponsored by the United States Government. While this document is believed to contain correct information, neither the United States Government nor any agency thereof, nor The Regents of the University of California, nor any of their employees, makes any warranty, express or implied, or assumes any legal responsibility for the accuracy, completeness, or usefulness of any information, apparatus, product, or process disclosed, or represents that its use would not infringe privately owned rights. Reference herein to any specific commercial product, process, or service by its trade name, trademark, manufacturer, or otherwise, does not necessarily constitute or imply its endorsement, recommendation, or favoring by the United States Government or any agency thereof, or The Regents of the University of California. The views and opinions of authors expressed herein do not necessarily state or reflect those of the United States Government or any agency thereof or The Regents of the University of California.

Ernest Orlando Lawrence Berkeley National Laboratory is an equal opportunity employer. 